\section{International Journal of Research in Social Science and Humanities (IJRSS)}

DOI: http://doi.org/10.47505/IJRSS.2020.9110
E-ISSN : 2582-6220

Volume 1, Issue 3

Jul - Aug - 2020

\title{
Third Party Mediation in the Cote D'Ivoire Conflict, 2002-2012
}

\author{
JOSEPH C. EBEGBULEM Ph.D \\ Department of Political Science \\ University of Calabar
}

Nigeria

\begin{abstract}
Cote D'Ivoire which was considered as one of the richest and the most stable and peaceful countries in the West African subregion immediately after independence under the leadership of Felix Houphouet-Boigny, witnessed major leadership crises in the early part of the $21^{\text {st }}$ century. As the economy of the country began to decline after the death of its founding leader, Houphouet Boigny, it started to witness periods of protracted power struggle. The country which enjoyed relative peace after independence under its founding president, started slipping into conflicts under successive leaders in the $21^{\text {st }}$ century. The Cote D'Ivoire conflict which started in 2002 and ended in 2012 attracted the attention of global, regional and sub-regional organisations who volunteered to mediate in the conflict and negotiate peace between the conflicting parties to bring the hostilities to an end. The third party mediation which included the United Nations (UN), the African Union (AU), the Economic Community of West African States (ECOWAS) and France at one time or the other, got involved in mediation efforts aimed at bringing an end to the Ivorian conflict. This paper examines the background of the Cote D'Ivoire conflict and discusses the factors that were responsible for the conflict. The paper also reviews and evaluates third party mediation in the conflict, and concludes that external interests exacerbated the conflict, and that affected the peace process.
\end{abstract}

Keywords: Mediation, Conflict, Ethnicity, Regionalism, Security.

\section{BACKGROUND OF THE COTE D'IVOIRE CONFLICT}

Cote d'Ivoire is one of the French speaking countries in the West African sub-region. The country got her independence from France in 1960, and enjoyed relative peace under its first president, Felix Houphouet-Boigny who ruled the country from 1960 till 1993 when he died. Cote d'Ivoire which was considered one of the richest and most stable countries in West Africa was engulfed in conflict in September 2002 as a result of pressure on the economy and selfish political ambitions of the political class in the country. Consequently, the unfriendly and fractious relations that exist between the Ivorian citizens who see themselves as "real Ivorian" and 'foreigners' of Malian and Burkinabe heritage became the scapegoats in the process of pursuing such political ambitions. This gave birth to the term "Ivorite" (Ivoriannes) which was used as a political tool for exclusion. The "Ivorite" politics became a source of power struggle that manifested in Cote d'Ivoire after the death of President Houphouet-Boigny in 1993.

There was a political vacuum after the death of the president in 1993 which resulted in a protracted power struggle. The concept of Ivorite as a tool of exclusion became more pronounced as the economy began to decline. The Ivorite policy was enunciated by Housphouet-Boigny's successor, Mr. Konan Bedie. According to Lynne (2004), "the Ivorite policy sowed a seed of paranoia, impoverished the foundation of community life, and produced an Ivorian society that was characterized by fear" (Lynne, 2004:18). Communities see each other as enemies and antagonists on the basis of identities which became fixed.

The policy of Ivorite excluded individuals who were not born of Ivorian parents from contesting elections. This is the case with Alassane Quattara who comes from the immigrant-heavy northern part of Cote d'Ivoire. Alassane Quattara was excluded from the presidential race after he was accused of descending from Burkinabe parents. Bedie's Ivorite policy and his tight grip on the political life of Cote d'Ivoire created ethnic tension which would trigger crisis in the long run.

Laurent Gbagbo proclaimed himself winner of the presidential election of 2002 after refusing to admit defeat. There was a popular revolt in Cote d'Ivoire that year as a result of this subversion of democracy. This was followed by a brief civil war 
between 2002 and 2004, with some lingering conflicts between Laurent Gbagbo's government and a northern rebel movement. Commenting on the factors responsible for this rebellion, McGovern (2011) stated that "the rebellion was sparked mainly by the fragility of democratic institutions, economic issues, and ethnic tensions due to the large number of immigrants in the country and discrimination towards people of Burkinabe origin who make up a significant percentage of the population in the northern part of the country" (McGovern, 2011:23).

Three prominent politicians contested the 2010 presidential election in Cote d'Ivoire. They were Alassane Quattara, Laurent Gbagbo and Henri Konan Bedie. Henri Bedie was eliminated in the first round of the elections which was conducted on October 31, 2010, leaving Alassane Quattara and Laurent Gbagbo to compete in the second round of elections which was conducted on November 28, 2010 (Hellweg, 2012).

With 54\% of the total votes cast in favour of Alassan Quattara against Laurent Gbagbo's 46\%, the Cote d'Ivoire Election Commission (CEI) declared Alassane Ouattara the winner of the election four days after the second round of elections. According to McGovern, "while international observers declared the elections free and fair, albeit reporting spontaneous violent incidents due to ethnic tensions between North and South, the Cote d'Ivoire constitutional court declared the elections fraudulent, and excluded votes from certain constituencies of the North" (McGovern, 2011:26).

Consequently by excluding votes from the Northern region where Alassande Quattara was favoured to win, the constitutional court argue that the Cote d'Ivoire Election Commission do not possess the authority to announce the results of the election as the deadline for the announcement of the results was over and victory was attributed to Laurent Gbagbo. Based on the results and pronouncement of the Cote d'Ivoire Election Commission, Alassane Quattara maintained that he was the winner of the presidential election, as he argued that the action of the constitutional court represents an abuse of power. Ignoring the declaration of Alassane Quattara as winner of the election by the Election Commission, military officers stood behind Laurent Gbagbo, even though the international community supported Alassane Quattara's declaration of victory. The result of this confusion was two inauguration ceremonies and competing claims to power that ignited the second crisis which started in 2011.

\section{FACTORS RESPONSIBLE FOR THE COTE D'IVOIRE CONFLICT}

While many scholars and writers on the Ivorian conflict have associated the conflict with the post-colonial administration, others have attributed it to economic and socio-cultural factors. Cote d'Ivoire's political upheavals have remained latent before the 1980's when the country started witnessing confrontation among the government, politicians and activists. The leadership style of President Houphouet Boigny which was authoritarian in nature created a lot of tensions and grievances among the Ivorian people. These tensions and grievances which culminated into political power struggle, characterized by military coups were indicators of political crisis. The overall security situation in the West African sub-region where common intra-state conflicts spread across the national borders, thus affecting the security of the neighbouring states is another contributing factor to the origin of the conflict in Cote d'Ivoire. Based on the afore-stated problems, this study will discuss some of the factors that gave rise to the conflict in Cote d'Ivoire.

The first factor to be discussed is the system of governance and succession in Cote d'Ivoire. According to Konate (2004), the system of government which Houphouet Boigny, the first Ivorian president established was characterized by personal loyalty to him built on the culture of dialogue and peace. Konate notes that the president's system of governance was based on political patronage which characterize the Ivorian public service at all levels. Patronage took the form of political appointments and monetary inducements. The monetary inducements came from rents extracted from the plantation economy through La Caisse de stabilization de products Agricoles (CAISTAB). CAISTAB is the central marketing organization. Commenting on the role of CAISTAB in the patronage system, Banegas (2006:537) states that "CAISTAB guaranteed producer prices which were about 50 percent of the global market prices. The surplus was the main resource that supported the patronage system." Banegas went further to explain how the patronage system was used to silence critics of government by co-opting potential opponents into the political elite with guaranteed privileges. He asserts that "the patronage system was reinforced by co-optation of potential opponents and pressure groups, both ethnic and professional groups, into the political elite and in the form of privileges as well as strong rule that silenced critics" (Banegas, 2006:538).

The sustainability of the governance system depended on economic growth. In other words, the system was sustainable as long as there was continuous economic growth. This system which was based on political patronage did not engender national cohesion because it was deprived of legitimacy, mass participation and political consciousness as it was designed to favour a few privileged individuals. These were primarily the plantation owners who invariably were the government leaders. Thus, government policies were more favourable to the plantation owners than any other individual or group of individuals in the 
Ivorian society. In this context as observed by (Crook 1990:26), "the state and the political elite became a source of accumulation and patronage, and state power became an instrument for the survival and wealth accumulation of the elite rather than the survival of the nation." Consequently, what constitutes state interest is determined by the elite whose interest is considered above state interest.

The structure of the state which was determined by the few political elite lacked the mobilization of civil society associations, class or interest aggregation did not have any agreed identity or legitimacy. Crook observes further that "security tended to focus on the regime which invariably influenced political choices to the detriment of the state' (Ibid). The basis of the existence of the state is thus, threatened by the fallout of this system of governance. Corroborating Cook's observation, Bakary (1997:70) notes that "the roots of the crisis were in the system of governance itself as the dwindling revenue creates a mismatch between available resources and requests from opponents and pressure groups." Bakery maintains that, with the liberalization of both the political space and the agricultural sector (with dissolution of CAISTAB), the basis for regulating political tensions ended in open manifestations of dissensions and violent conflicts. This development, according to Banegas (2006) was one of the main catalysts that eventually led to the 1999 coup d'etat and subsequently armed conflict in 2002 .

Yere (2007), in agreement with Bakary's (1997) and Banegas' (2006) analysis on the system of governance, concluded that, within the Ivorian context, the nature of the state and the question of nationhood was determined in terms of the elite and regime security.

The governance system witnessed lack of mass mobilization; there was rather an elitist club in the Ivorian society which derived its legitimacy from rents got from the plantation economy. This became a threat to the Ivorian nation which manifested in the armed conflict.

Another source of the conflict which was related to the system of governance was the question of succession. For the security of the regime, Houphouet Boigny did not groom or encourage his potential successors because he believed that doing so could pose a challenge to his authority. Based on this, Banegas (2006) reasoned that this could be the reason for appointing Alassane Quattara as Prime Minster since Houphouet Boigny reasoned that Alassane Quattara could never become president in view of his northern background and lineage with Burkina Faso. Akindes (2003) similarly contends that Houphouet-Boigny's caution was linked to his desire to maintain elite cohesion. Elite and regime security thus, took the center stage over national security. Security of the regime was responsible for the lack of any defined succession plan. This had dangerous consequences for national security as divisions and absence of unity among the elite created the platform for the conflicts.

Ethnicity and regionalism constitute another factor that gave rise to the Ivorian conflict. As a multi-ethnic society, Cote d'Ivoire has over 60 ethnic groups. The major ethnic groups are the Mandes in the West and the Northwest; the voltaic in the Northeast; the Krahn in the Southwest, the Akans in the southeast (Akindes, 2003). The failure of the elite to build a cohesive Ivorian national identity has remained a security threat to Cote d'Ivoire (Bakary, 1997). The threat posed by ethnicity was, according to Daddieh (2001:15) "derived from the system of ethnic stratification based on an alleged methodology that ranked the ethnic groups in order of superiority." This, he said "placed the Mande first, followed by the Akan and Krahn, a development that changed the ethno-religious balance and threatened the perceived interests of the elites." Daddieh (2001) however, note that this classification was redefined by the Akan group that dominated the Ivorian political class after independence, placing them at the top, followed by the Mandes and Krahn.

By 1990, the ethno-regional factors began to aggregate; giving room for political mobilization (Akindes, 2003). At this juncture, it has become obvious that ethno-regional coalition is threatening to polarize the country, as some areas became mobilization centres for ethno-regional interests. Linked to ethnicity therefore, was the question of regionalism. There was disparity in regional development between the South and North due to the way the economy was structured before independence. The northern region of Cote d'Ivoire was not as developed as the Southern region. Dozon (1977) cited in Institute for Security Studies (2007:2) notes that "within this context ethnic significance became overloaded with the sense of unequal structuring of Ivorian society and manipulation by the colonial states." Unequal access to power and disparity in socio-economic development increased the tempo for ethno-regional demands ignited by identity politics. "Thus, the myopic exploitation of ethnicity and regionalism to perpetuate regimes was a threat to national cohesion and a fundamental grievance that led to the conflict in Cote d'Ivoire." (Ibid).

Migration is another factor that played prominent role in the Ivorian conflict. The country's liberal land policy encouraged migration to the cocoa growing areas of the country. This later became part of the source of tension long before the crisis started in 2002. Almas (2007:12) has argued that "the political history of the Ivory coast is intimately linked with migration." Whereas migrants were a source of security to Houphouet Boigny and his government, they were a source of threat to successive regimes after him and the nation at large. Yere (2007) who highlights internal and external migration as a source of conflict in Cote d'Ivoire states that about 30 percent of the populations of Cote d'Ivoire are believed to be descendants of first and 
second generation of immigrants. Given the pervasiveness of migrants in every echelon of the Ivorian society, it was not surprising that relations between the indigenes and foreigners have been tense since the pre-independence period, leading to a sporadic xenophobic attacks by different ethnic groups in Cote d'Ivoire.

According to Akindes (2003:18), "the philosophy of using factors of production, mainly labour and capital, manifested in the "open-door" policy on immigration that produce a steady flow of foreign migrants into the rural areas intended to benefit the elites". Akindes contention was buttressed by Woods $(2003 ; 648)$ who highlights that "this liberal attributes to migrant labour and capital was encouraged by incentives for migrants to own land and participate in elections while an attractive investment code encourage migrant entrepreneurs, particularly French and Lebanese." Woods believes that "this was a recipe for future conflict".

Riehl (2007) has examined the security significance of migrants under Houphouet Boigny, and concluded that it was two-fold. The first, according to him, were African migrants who provided cheap and available labour while the second were Europeans (French) and Lebanese migrants who made available foreign capital for the development of the plantation. The patronage system that kept the regime in power was strengthened by the rents received from both labour and investment. Secondly, Crook (1990) posits that, the high level of expatriate manpower in the early years of independence was part of a strategy by the Ivorian leaders to control the administration and by extension, control the possibility of mass political mobilization by workers. Based on the opportunity given to them to vote during elections, migrants aligned themselves to the ruling party which they see as their guarantor.

In contrast to Houphouet Boigny's "open-door" policy on immigration, Bedie perceived migrants as "invaders" who he sees as a threat to national security. A report by the Economic and Social Council of the United Nations confirmed Bedie's fears. A section of the report quoted by Mousa (2009:4) warned that:

The tolerable threshold (of immigration) has been largely exceeded in our country, exposing it to serious risks to the socio-demographic equilibrium and to the social unity of Cote d'Ivoire - each country must in its interests, take adequate steps to avoid being invaded by foreigners. It is simply a matter of safe-guarding the nation.

Highlighting the influx of migrants as part of social problems in Cote d'Ivoire and a source of threat to national security, Djobo (2009:46) argues that;

While migrants were exploited for regime interests, the phenomenon increased pressure on arable land; created concerns over the status of children of migrants born and brought up in Cote d'Ivoire; highlighted inter-community conflicts; placed a strain on basic social infrastructure; and led to a rise in crime, among other problems. These are factors that have enormous consequences for national security.

The potential consequence of the manipulation of migration for national identity which emerged in 1990s degenerated into an identity crisis for generations of migrants and Ivoirians of northern extraction. This was the defining issue of armed conflict in Cote d'Ivoire.

The works of scholars on the causes of the Ivorian conflict show that, even though scholars have covered various aspects of the causes of the conflict, the concept of identity politics was not applied comprehensively enough in the analysis of the causes of the conflict. Scholars like Chirot (2006); Kirwin (2006); and Langer (2005) emphasized on the ethnic causes of the conflict. Kirwin (2006) argues that, the security dilemma of Cote d'Ivoire was based on shared North/South identity even though the Ivorian society is composed of different ethnic groups.

Banegas and Marshal-Fratani (2007) similarly identified identity politics as the basis of the spillover of the conflict into a regional and international security issue. Akindes (2003) linked the conflict to politics of patronage employed in the immediate post-independence period until 1993. In linking political and economic inequalities with ethnicity, Langer (2005) identified what he calls "horizontal socio-economic inequalities" between the North and South divide coupled with "political horizontal inequalities" among the elites as the root cause of the Ivorian conflict. He note that inequalities created opportunities for regimes to mobilize and garner support along ethnic lines. Almas (2007), on his part emphasized the economic crisis in the eighties as the main cause of the conflict. His explanation according to Collet (2006), drew linkage between externally imposed Structural Adjustment Programme (SAP) and subsequent deterioration of socio-economic conditions as the cause of the conflict. Thus, economic concerns and the politics of exclusion created a polarization of the north/south division.

The operation of the threat to national security in Cote d'Ivoire divided the country into two distinct parts namely, the Muslim north and the Christian/Ammist South. Nordas (2007) however, contested the characterization of the conflict as a religious war. He delineated exclusionary identity politics as the underlying cause of the Ivorian conflict. What is lacking in the 
above explanations by these various scholars is an adequate discussion on well-defined threats to national security and the failure of successive Ivorian governments to convert economic prosperity and periods of relative stability into building a national cohesion. The role of the ruling elite, reflected in the attitudes of the various regimes, has been largely overlooked as one of the main causes of the conflict that resulted to security challenges in Cote d'Ivoire.

\section{THE "IVORITE" FACTOR}

The combination of the afore-stated causes of the Ivorian conflict - the system of governance, migration, ethnicity and regionalism resulted in identity crisis. In their desire to maintain the status and positions of the elite in the midst of socioeconomic challenges, successive Ivorian leaders after Houphout Boigny accommodated migrants in order to enhance their legitimacy and protect their regimes. However, these regimes later perceived migrants as a threat to the survival of both the nation and their regimes. This threat was embodied in an ideology that distinguished between nationals and foreigners: "Ivorite" (Bangas, 2006).

Bangas (2006:540) defines Ivorite as an "instrument of stigmatization and discrimination". Riehl (2007:34) defines it as "a nationalist dogma based on a condition of "pure" Ivorian ancestry in order to enjoy political rights." Bouah, an ethnosociologist cited in (Akindes, 2003:27), defines the socio-cultural foundations of Ivorite as a "set of socio-historical, geographical and linguistic data which enables us to say that an individual is a citizen of Cote d'Ivoire or an Ivorian. The person who as serts his "Ivorite" is supposed to have Cote d'Ivoire as his country, born of Ivorian parents belonging to one of the ethnic groups native to Cote d'Ivoire."

The Ivorite ideology manifested as an instrument for political exclusion at the tribal and regional levels. "Tribal Ivorite sought to safeguard the positions of the Akans by emphasizing Akan supremacy based on anthropological constructs which viewed Christianity as an element of Ivorian identity" (Banegas and Marshall-Fratani, 2007:21). According to Banegas and Marshall-Fratani, the regional manifestation identified an Ivorian with the South, West and the centre to the exclusion of those from the north who are mainly Muslims, and for historical reasons ethnically affiliated with Burkina Faso, Mali and Guinea.

"Thus Ivorian identify became a combination of migrant status, ethnicity, religion and language; a concept that implicitly or explicitly included Ivorian nationals who settled in other parts of the country, thereby alienating a large number of Ivorians by virtue of their ethno-religious affinity, with the propensity of dividing the country into two". (Banegas and Marshall-Fratani, 2007:28).

The consequences of this construct, according to Kohler (2003) was the emergence of two types of Ivorian citizens categorized into pure blooded Ivorian and Ivorians whose parents are without Ivorian citizenship. Similarly, Konate (2004:8) observes that "it also created three levels of non-Ivorian identities, namely, French, immigrants from West Africa, and Ivorians whose geographical origins, ancestry, religion and family name made them doubtful nationals." Cote d'Ivoire was thus, grouped into two regional geopolitical blocs of north and south which eventually formed the basis of armed conflict in Cote d'Ivoire.

Almas, (2007) notes that Ivorite ideology was first introduced in Ivorian politics by Gbagbo in his attempt to disfranchise citizens who were not born of Ivorian parents in the 1990 elections, thereby projecting himself as a defender of Ivorians' interests', This prevented many native Ivorians, especially those who are from the northern part of Cote d'Ivoire from exercising their right to vote and to be voted into elective offices. The "Ivorite" factor became a threat to national security, considering the fact that the population of immigrants in Cote d'Ivoire is more than 40 percent.

Identifying exclusionary politics as a contributing factor to the Ivorian conflict, Almas (2007:15) states thus:

It is therefore, not surprising that mutiny and the subsequent armed groups that emerged in 1992 and 2002, identified the elimination of exclusionary politics as their main objective. It is therefore, evident that identity politics and the definition of Ivorian were measures to ensure the security of the regimes. The result was the unintended consequences of creating a threat to national security and cohesion, a threat that became the heart of the armed conflict in 2002 .

The Ivorite factor was an important component of exclusionary politics that was used by successive leaders after Houphouet-Boigny for elite and regime security. Many politicians from the northern region of Cote d'Ivoire were prevented from contesting in elections because they are not full-blooded Ivorians. The Ivorite factor thus became a source of conflict in Cote d'Ivoire.

\section{FRANCE AND THE COTE D'IVOIRE CONFLICT}


France was directly involved in the Ivorian conflict. The involvement of France in the conflict was based on historical and geo-strategic factors. Cote d'Ivoire was the most important country to France among the French-speaking countries in the West African sub-region. Cote d'Ivoire was a colonial state of France and the biggest trading partner of Franc in West Africa.

According to Kohler (2003), Cote d'Ivoire's exports to and imports from France stood at 13.3 percent and 22.6 percent respectively. Kohler notes that over 16,000 French citizens were living in Cote d'Ivoire, while France controlled about 80 percent of the Ivorian economy prior to the beginning of the Ivorian conflict. Many subsidiaries of French companies were operating in strategic sectors of the Ivorian economy.

With her investment in Cote d'Ivoire, and many of her citizens living there, France was naturally inclined to protect her citizens and business interests in Cote d'Ivoire. This according to Nabakwe (2007), made France a critical stakeholder in the Ivorian conflict. Nabakwe's position was corroborated by Moorhead (2002:62) who asserts that "France's concern over development in Cote d'Ivoire is not only politically motivated but militarily and economically as well. The former colony has for a long time been the investment platform for French companies in West Africa." According to him, "France is the biggest single trading partner, defense supplier and bilateral aid donor to Cote d'Ivoire"

On the political front, Nabakwe argues that "France needs an individual who can consistently be used to monopolise French interest by ensuring that political decisions that are taken by the government of Cote d'Ivoire were in favor of the French." (Nabakwe, 2007:46). The struggle for political leadership in Cote d'Ivoire, according to him is related to the actual or perceived protection of French control that different Ivorian leaders can offer. Scholars like Nabakwe (2007) and Souare (2006) have argued that France supported the rebels in the first conflict in Cote d'Ivoire and Alassane Quattara in the second conflict because France has reasoned that Laurent Gbagbo is not the kind of leader that would support and protect French interest in Cote d'Ivoire. According to Souare (2006), French support for the rebels was based on the perception that Gbagbo was a threat to French interest in Cote d'Ivoire, considering his nationalist credentials. Souare notes that "Gbagbo had long advocated a reduction of the country's reliance on France and diversification of the Ivorian economy from French monopoly. This put him on collision course with France" (Souare, 2006:62). Based on the report of the International Crisis Group of 2003, French multinational companies which have significant investments in Cote d'Ivoire were accused of financing the rebels for fear of nationalization of their interests (International Crisis Group, 2003).

The attitude of France during the first and second conflicts in Cote d'Ivoire has led many observers to believe that her role in both conflicts may have exacerbated and prolonged the conflict situation. To these observers, France's role in the Ivorian conflict was selfish. They affirm that this selfish attitude has always been part of her African policy. One of these observers is Banegas (2006:48) who believes that 'the situation in Cote d'Ivoire is a result of France's African policy. He believe that France maintained a selfish African policy, which did not allow for true democracy to thrive in any of her former colonies. Banegas' position is corroborated by Moorhead (2002:63) who argues that "France cares little about the plight of Africans, especially when it comes to her former colonies. It is rather in her interest to sow divisions among Africans on the basis of religion, nationality, ethnicity and resource, the root causes of coups in Africa, Cote d'Ivoire included." Moorhead notes further that France's response at the start of the conflict in September was the protection of her interest and nationals as well as citizens from other Western nations before showing any interest in the resolution of the conflict.

"It was also interesting to note that in the wake of the uprising, Ivorians in the region where the French concluded their rescue operations were left to their fate" (Moorhead 2002:63). It can therefore, be concluded that French involvement in the Ivorian conflict was dictated by selfish national and economic interests.

\section{THIRD PARTY MEDIATION IN THE COTE D'IVOIRE CONFLICT}

Mediation efforts were made by regional and international organizations like the Economic Community of West African States (ECOWAS), the African Union (AU), the United Nations (UN) and France at one time or the other to advance the peace process and bring an end to the Ivorian conflict. Kirwin (2006) highlights that the third party mediation processes involved the signing of Accords by representatives of government and rebel groups as a process of negotiating peace between the warring parties to end the hostilities.

\subsection{ECOWAS Mediation}

ECOWAS was instrumental in the resolution of the Ivorian conflict. The regional organization was created, among others, to maintain peace and security in the West African sub-region. After weighing the gravity of the Ivorian conflict, its implication and the consequent threat to the region's stability, ECOWAS responded with measures to resolve the conflict. After the regional organization's first attempt at mediating a peace process between the government and the rebels when the conflict began, it continued to collaborate with other organizations to seek a lasting solution to the conflict.

ECOWAS Heads of government formed a six-nation mediation group in the wake of the Ivorian conflict in 2002 for the purpose of exploring avenues for a peaceful resolution of the conflict. The group which comprised of Ghana, Guinea-Bassau, Mali, Nigeria, Niger and Togo made frantic efforts to bring the warring parties to the negotiating table in order to restore normalcy 
in Cote d'Ivoire. ECOWAS supervised the signing of many agreements to end the hostilities in the country. These agreements include the Linas Marcoussis Accord, Abidjan Ceasefire, Lome and Accra I, II and III, Pretoria I and II agreements (Nathan, 2004). Prior to the signing of these agreements, ECOWAS member states met in Accra, Ghana on the $29^{\text {th }}$ of September, 2002 for the purpose of preparing ground for peace negotiations between the government and the rebels. On October 17, 2002, the organization supervised the signing of the Cease-fire agreement in Abidjan which was followed by the Lome Agreement on November 1, 2002. Kirwin (2006) notes that the outcome of the Lome Agreement was the deployment of ECOWAS and French forces for peace enforcement, and the creation of a bufferzone (zone of confidence).

With the signing of these agreements by the warring parties, there was temporary suspension of hostilities, even though the agreements were later undermined by both parties to the conflict. Failure by both parties to honour and implement the various agreements signed by them under the supervision of ECOWAS necessitated the mediation of the African Union (AU) (Kirwin, 2006).

\subsection{The African Union (AU) Mediation}

According to former president of Nigeria, Olusegun Obasanjo, "a threat to Cote d'Ivoire is a threat to the African Union, especially, when the AU had taken a decision to ensure the sustenance of democracy in each African country."

Though the African Union and its Peace and Security Council, provided the necessary assistance needed for the continuation of the peace process in Cote d'Ivoire. Under the auspices of the African Union, Thabo Mbeki, led a mediation process to resurrect the peace process and ensure the implementation of the Lina-Marcousis and the Accra peace agreements. With the collaboration of the African Union and ECOWAS, Mbeki applied pressure on the Ivorian government and the rebels to end the conflict.

Thabo Mbeki emphasized that peace could return to Cote d'Ivoire again if the African Union and ECOWAS work collaboratively in finding a peaceful resolution to the conflict. Kirwin (2006) observed that the Pretoria I and II peace agreements were the products of Mbeki's endeavour on April 6, and June 29, 2003 respectively to resolve the conflict.

The Pretoria I agreement, according to Nathan (2004:22) "sought to rectify outstanding issues of disarmament and dismantling of the militia throughout the entire territory that undermined the implementation of Linas-Marcousis agreement. It was the failure to address such issues that led to the signing of the second Pretoria agreement".

\subsection{The French Mediation}

Protection of French citizens in Cote d'Ivoire was a priority to France when the conflict started in September, 2002. This was why France sent troops to Cote d'Ivoire to protect her citizens there. While reaffirming her support to African efforts to end the conflict, France offered to hold peace talks in Paris between the Ivorian government and the rebels. These peace talks gave birth to the Linas-Marcoussis Agreement which made provision for the establishment of an all-inclusive government of national reconciliation with wide executive powers. The agreement was an effort by France to mediate peace in the Ivorian conflict so that her economic interest and investments in Cote d'Ivoire will be protected, since France believes that her economic investments in Cote d'Ivoire would be in great danger if the conflict is allowed to continue, hence the need by France to facilitate the peace process that will end the conflict. The need to protect French citizens who were resident in Cote d'Ivoire during the conflict gave impetus to France's efforts in exploring ways of restoring peace in Cote d'Ivoire.

\subsection{The United Nations (UN) Mediation}

In an effort to find a quick resolution of the Ivorian conflict, the United Nation Mission in Cote d'Ivoire (MINUCI) arrived in the country on May 13, 2003 as part of the mediation process. The mandate of MINUCI was the facilitation and implementation of the Linas-Marcoussis agreement by the government and the rebels. There was a military component of (MINUCI) to complement the operations of the French and ECOWAS forces.

The United Nations Mission in Cote d'Ivoire (MINUCI) was replaced by the United Nations Operations in Cote d'Ivoire (UNOCI) on April 4, 2004. UNOCI was established by the United Nations Security Council Resolution 1528 of February 27 , 2004 (Chirot, 2006). It was authorized by the Security Council to adopt all the available means to carry out its mandate within its capabilities and its area of deployment. Such mandate include the following:

(i) monitoring the cessation of hostilities and movements of armed groups;

(ii) disarmament and dismantling of militias;

(iii) reformation of the security sector;

(iv) protection of United Nations personnel, institutions and civilians;

(v) monitoring of the arms embargo;

(vi) support for humanitarian assistance;

(vii) support for the organization of open, free and transparent elections; 
(viii) assistance in the field of human rights (Chirot, 2006).

The United Nations played significant role of ensuring that the warring parties adhere strictly to the provisions of agreements signed to bring an end to the conflict.

\section{EVALUATION OF THIRD PARTY MEDIATION}

There has always been a third party involvement in the mediation process of most conflicts in Africa. Third party mediation may have succeeded in bringing the warring parties to agree on ways of resolving the conflicts, the desired result may be far from being achieved. Many factors account for the failure of third party mediation in conflict resolutions.

A third party whose interest is at stake in a conflict situation may be more interested in its own interests than the interests of the parties in the conflict. There is also the fear of favouritism where the third party may favour one conflicting party over the other. This aspect of the shortcomings of third party mediation was identified in the Ivorian conflict. Initially the government of President Laurent Gbagbo in Cote d'Ivoire was against the participation of Burkina Faso in any mediation process to end the Ivorian conflict because Burkina Faso was seen by the Ivorian government as a party to the conflict. France was also seen to be protecting her interest in Cote d'Ivoire rather than the interest of Cote d'Ivoire in the midst of the conflict.

To be an effective mediator, it is very important to have the necessary and adequate background of the conflict. The nature of the dispute that may have given rise to the conflict must be well understood. In most cases, the third party in a conflict situation is not conversant with the background of the conflict, and may not even understand the nature of the dispute before taking the role of a third party mediator. In order to develop appropriate and effective mechanisms for resolving any conflict, third party mediators must understand the root causes of the conflict. They must also remain objective and impartial in their mediation process (Nathan, 2004). Nathan advices further that third parties in any conflict should not have any interest whatsoever that may detract their efforts at resolving the conflict.

The Ivorian conflict could not be quickly resolved through third party mediation because the issues that gave rise to the conflict needed to be properly understood. One of these issues is the question of naturalization which was endemic in Cote d'Ivoire before and during the conflict. It did not allow for true and genuine reconciliation to occur, even through the mediation process. Naturalization gave birth to an ugly attitude that permeated the mediation process in Cote d'Ivoire and exhibited by the warring parties. This is a contributing factor to the non-implementation of various signed agreements between the government and the rebels.

ECOWAS was not able to meet the challenges of resolving the Ivorian conflict alone because the regional organization lacked the capacity, skills and resources needed for the resolution of the conflict. The involvement of the United Nations and France, and their subsequent influence on the direction of the conflict was as a result of the inability of ECOWAS to handle the mediation process from the start of the conflict to its end. The interference by some member states of the United Nations and ECOWAS was anchored on national interest and suspicion.

The inability of actually taking up the challenges of acting on decisions and directives by ECOWAS hampered the consistency of the regional organization to achieve maximum result in conflict resolutions in the sub-region, with the Ivorian conflict as an example. There was no set standard by ECOWAS to compel the Ivorian government and the rebels to comply with decisions and agreements that were reached for the resolution of the conflict.

The mediation process in Cote d' Ivoire was, to some extent, affected by some external interests. Burkina Faso, Mali and Niger were involved in the conflict since most of the so-called "non-Ivorians" whose identities became a major factor in the conflict were from these countries. Banegas and Marshall-Fratanic (2007) have argued that it could have been counter-productive if any of these countries have participated in the mediation process considering their relationships with the "non-Ivorians" in Cote d'Ivoire. The leadership of the Ivorian government, according to McGovern (2011), accused Burkina Faso of supplying guns to the rebels which they used in fighting the government. McGovern however, observed that "it is paradoxical that the final peace deal which signified the end of the conflict was hosted in Ouagadougou, the capital of Burkina Faso. This could show that suspicion has been cleared on the part of Burkina Faso and President Gbagbo, given the assurance that there will be no more troubles coming from Burkina Faso." (McGovern 2011:18).

Mediation efforts to end the conflict in Cote d'Ivoire did not achieve the much desired result as a result of the above stated reasons. According McGovern (2011:20) "the issues were addressed from a political angle, the parties did not feel that they owned the process until the Ouagadougou peace Accord." He maintains that there was a low level of confidence between the warring parties leading to a consistent faltering of trust for the various mediators. While Okereke (2012:11) argues that the mediation process in Cote d'Ivoire suffered from what he describes as "verbose mandates and mission statements and peace deals, ambiguity and lacked clearly defined goals leading to the setting of unrealistic time-frame," Williams (2011) averred that national interests and influence intruded on the mediation processes which had far-reaching consequences, even to the extent of contributing to the escalation of the conflict.

\section{CONCLUSION}


The Cote D'Ivoire conflict was associated with bad post-colonial administration which resulted to socio-economic woes and political crises. In other words, the causes of the conflict originated from Cote D'Ivoire's political and economic circumstances. While some of these circumstances were a consequence of the legacy of French rule, to a large extent, they were partly due to the strategies adopted by various regimes in Cote D'Ivoire to secure their administrations following the country's independence in 1960.

After the death of Houphouet-Boigny, the first president, ethnicity and regionalism became pronounced, as regime security became intertwined with the security of ethnic groups. This brought to the fore the fractious nature of Ivorian society. Although there was a form of ethnic balancing, ethno-regional and ethno-religious identities were not subsumed under a single national identity. This was partly due to the system of governance, as well as ethnic allegiance that traversed the borders of Cote D'Ivoire. This underscored the problem of legitimacy of the various regimes.

In the absence of legitimacy and national cohesion, the system was vulnerable to manipulation by various regimes to suit their interests, and subsequently crumbled under pressure from the various contending groups in the state. It is evident therefore, that the roots of the Ivorian conflict were the failures of the state, represented by the ruling elite, to perform its fundamental task, namely building national cohesion, especially in periods of economic prosperity.

Notable global, regional and sub-regional organisations like the UN, AU, and ECOWAS at one time or the other carried out mediation efforts aimed at advancing the peace process to bring an end to the Cote D'Ivoire conflict. These organisations formed the core third party mediation in the conflict. The conflict could not be resolved through third party mediation earlier as thought, since the political, economic and ethnic issues presented were endemic and needed to be properly grasped.

\section{REFERENCES}

Akindes, F. (2003). “Cote d'Ivoire: Socio-political Crises, 'Ivoirite' and the Course of History”, African Sociological Review, vol. 7, No. 2.

Almas, G. (2007). "The Political Implications of Economic Adjustment: Crisis, Reform and Political Breakdown in Cote d'Ivoire", in C. Obi (ed.). Perspective on Cote d'Ivore: Between Political Breakdown and Post-Conflict Peace. Discussion paper 39, Nordiska Africa institute, Uppsala.

Bakary, T. (1997). "Political Polarization over Governance in Cote d'Ivoire" in I. W. Zartman (ed.) Governance as Conflict Management: Politics and Violence in West Africa. The Brookings Institute.

Banegas, R. (2006). "Cote d'Ivoire: Patriotism, Ethno-nationalism and other African Modes of Self-Writing”, African Affairs, Vol. 105, No. 421.

Banegas, R. and Marshall-Fratani, R. (2007). "Cote d'Ivoire: Negotiating Identity and Citizenship", in M. Boas and K. Dunn (eds.) African Guerillas, Raging against the Machine. London: Lynne Rienner.

Chirot, D. (2006). "The Debacle in Cote d'Ivoire", Journal of Democracy, Vol. 17, No. 2.

Crook, R. (1990). "Politics, the Cocoa Crisis and Administration in Cote d'Ivoire" The Journl of Modern African Studies, Vol. 28, No. 4.

Daddieh, C.K. (2001). "Election and Ethnic Violence in Cote d'Ivoire: The Unfinished Business of Succession and Democratic Transition" African Issues. Vol. 29 N0. 1\&2

Djobo, E. B. (2009). "The Experience of Cote d'Ivoire in Handling Migration”, Paper Presented at the Symposium on Global Migration, Pretoria, February 19, 2009

Dozon, J. (2001). "Post-Prophetism and Post-Houphouetism in Ivory Coast”, Social Science Compass, Vol. 48, No. 3, Pp.369-385 International Crisis Groups, (2003). "Cote d'Ivoire: The War is not yet over". Africa Report, No. 62

International Crisis Group, "Conflict History: Cote d'Ivoire". www.crisisgroup.org/home/index.cmf?action=conflictsearch \& $1=1 \& \mathrm{t}=\mathrm{eCountry}=32$ (Accessed April 22, 2014)

Kirwin, M. (2006). The Security Dilemma and Conflict in Cote d'Ivoire. Nordic Journal of Africa Studies, Vol. 1, Pp.42-45

Kohler, J. (2003). "From Miraculous to Disastrous: The Crisis in Cote d'Ivoire, Centre for Applied Studies in International Negotiations" (CASIN) Geneva. http://www.casin.ch/web/pdf/cotedivoire.pdf Accessed April 22, 2014)

Konate, A. S. (2004). "The Politics of Identity and Violence in Cote d'Ivoire" West Africa Review, Vol.3, No.5, P.34

Langer, A. (2004). "Horizontal Inequalities and Violent Group Mobilization in Cote d'Ivoire", Oxford Development Studies, Vol. 33, No. 1, Pp.25-45

Lynne, R. (2004). Governance as Conflict Management. Washington D.C.: Brookings Institute Press

McGovern, M. (2011). Making War in Cote d'Ivoire. Chicago: University of Chicago Press

Moorhead, M. (2002). “Why Did US and French Troops Invade Ivory Coast?" Workers World. http://www.hartfordhwp.com/archives/27c/ 385.html (Accessed August 20, 2014) 
International Journal of Research in Social Science and Humanities (IJRSS), Vol .1(3)，July-Aug - 2020

Nabakwe, R. (2007). "French-Africa Policy Partly to Blame for Ivorian Crisis," Pan African News Agency. http://www.hartfordhwp.com/archives/27c/382.html (Accessed August 20, 2014).

Okereke, G. (2012). "Crime and Punishment in Cote d'Ivoire". International Journal of Comparative and Applied Criminal Justice, Vol. 36, No.1, Pp. 61-72

Riehl, V. (2007). "New War-Old Peace: About the Descent into Civil War in Cote d'Ivoire and its Absence in Ghana". In C. Obi (ed.) Perspective on Cote d'Ivoire: Between Political Breakdown and Post-Conflict peace, Discussion paper 39, Nordiska African Institutet, Uppsala.

Yere, H. M. (2007). "Reconfiguring Nationhood in Cote d'Ivoire?" in C. Obi (ed.) Perspectives on Cote d'Ivoire: Between Political Breakdown and Post-Conflict Peace, Discussion Paper 39, Nordiska African Instituted, Uppsala. 